\title{
PENGARUH KOMUNIKASI, MOTIVASI DAN IMBALAN TERHADAP KINERJA PEGAWAI SEKRETARIAT DPRD PROVINSI SUMATERA SELATAN
}

\author{
Oleh : Zahruddin Hodsay \\ (UNIVERSITAS PGRI PALEMBANG)
}

zhodsay@gmail.com

\begin{abstract}
Abstrak- Penelitian ini bertujuan untuk mengetahui apakah komunikasi, motivasi dan imbalan mempunyai pengaruh yang signifikan terhadap kinerja pegawai Sekretariat DPRD Provinsi Sumatera Selatan. Populasi sebanyak 111 orang, teknik pengambilan sampel adalah teknik cluster random sampling, sampel sebanyak 78 pegawai. Metode penelitian adalah metode survey yang bersifat kausalistik, sedangkan teknik analisis data adalah analisis regresi linier berganda. Hasil penelitian analisis statistik dapat disimpulkan bahwa secara simultan komunikasi, motivasi dan imbalan memiliki pengaruh yang sangat kuat terhadap kinerja pegawai Sekretariat DPRD Provinsi Sumatera Selatan ( $r=$ $0,875)$ dengan taraf signifikansi $F$ 0,000 <0,05. Namun secara parsial, hanya komunikasi yang mempunyai pengaruh yang signifikan. Sedangkan motivasi mempunyai pengaruh tetapi tidak signifikan dan imbalan tidak mempunyai pengaruh yang signifikan terhadap kinerja pegawai.
\end{abstract}

Kata Kunci : Komunikasi, Motivasi, Imbalan, Kinerja

Abstract- This observation has the aim to know whether communication, motivation and reward have a significant effect on the staff's performance the Secretariat DPRD South Sumatera Province. The population is a few 111 persons, the sampling technic taken is cluster technic random sampling, sampling as many 78 persons. The research method is the method of surveying which is causality, while the data analysis technic is double linear regression analysis. The result of this research statistical analysis, it can be concluded that the simultaneous way together communication, motivation and reward have the strong effect to the staff's performance the Secretariat DPRD South Sumatera Province $(r=0.874)$ with the significance level $F 0.000<0.05$. But partially, communication is only the way has a significant effect. While the other one is about the motivation has the un significant effect and the last its reward doesn't have any significant effect.

Keywords: Communication, Motivation, Reward, Performance.

\section{PENDAHULUAN}

Pelaksanaan otonomi daerah berdasarkan Undang-Undang Nomor 32 tahun 2004 tentang Pemerintah
Daerah dan Undang-Undang Nomor 33 tahun 2004 tentang Perimbangan Keuangan antara Pusat dan Daerah membawa peluang kepada daerah 
untuk melaksanakan pembangunan. Pemberlakuan otonomi daerah juga memberikan dampak yang sangat luas tidak hanya bagi penyelenggaraan pemerintah namun juga memberikan implikasi yang sangat substansial pada kehidupan masyarakat.

Penerapan dan implementasi Undang-Undang Nomor 32 tahun 2004 bukanlah hal yang mudah, karena diperlukan perangkatperangkat pendukung pelaksanaan untuk menyukseskan penerapan otonomi daerah. Keberadaan petunjuk pelaksanaan (juklak) dan petunjuk teknis (juknis) UndangUndang tersebut seperti Peraturan Pemerintah (PP) adalah indikasi yang kuat bahwa pemerintah sangat konsen terhadap penyelesaian masalah kesenjangan antara pusat dan daerah. Antara lain seperti Peraturan Pemerintah Pengganti Undang-Undang Nomor 3 tahun 2005 tentang Perubahan atas Undang-Undang Nomor 32 tahun 2004 tentang Pemerintah Daerah. Usaha ini juga didukung dengan keberadaan Peraturan Daerah yang menyesuaikan dengan UU Nomor 32 tahun 2004.

Pemberlakuan otonomi daerah tentunya akan sangat mempengaruhi struktur organisasi, juga pembiayaan sebuah departemen akan mengalami perubahan. Sebagai contoh adalah yang tertuang dalam UU Nomor 32 tahun 2004 pasal 12 ayat 1 yaitu urusan pemerintahan yang diserahkan kepada daerah disertai dengan sumber pendanaan, pengalihan sarana dan prasarana, serta kepegawaian sesuai dengan urusan yang didesentralisasikan. Oleh karena itu Pemerintah Daerah bukan hanya menyiapkan perangkat keras (hardware) seperti sarana kantor dan sarana fisik lainnya, tetapi juga harus menyiapkan perangkat lunak (software) dan aparatur pemerintah (Sumber Daya Manusia) yang berkualitas dan profesional demi tercapainya Good Governance.

Dengan diberlakukannya Undang-Undang Republik Indonesia Nomor 43 tahun 1999 tentang Perubahan atas UU Nomor 8 tahun 1974 mengenai Pokok-Pokok Kepegawaian yang berlaku untuk seluruh Pegawai Negeri di seluruh Indonesia, demikian juga halnya dengan pewagai di lingkungan Sekretariat DPRD Propinsi Sumatera Selatan. Undang-Undang tersebut mengamanahkan bahwa Pegawai Negeri sebagai warga negara, unsur aparatur negara, abdi negara dan abdi masyarakat.

Dengan paradigma baru Pegawai Negeri harus lebih mengutamakan kepentingan masyarakat dan wajib mentaati segala peraturan perundangundangan yang berlaku dan melaksanakan tugas kedinasan yang dipercayakan dengan penuh pengabdian, kesadaran dan tanggung jawab. Namun demikian masih ada saja kendala untuk mewujudkan 
Pegawai Negeri Sipil yang berkualitas. Masih banyak yang bekerja sekedar untuk mencari nafkah guna menghidupi keluarga. Bekerja sebagai formalitas dengan kegiatan apel pagi, absensi, kemudian mangkir tanpa peduli dengan tugas dan tanggung jawabnya, bekerja dengan malasmalasan, korupsi jam kerja, menggunakan fasilitas kantor untuk keperluan pribadi dan/atau keluarga dan berbagai permasalahan lainnya.

Dinamika organisasi dalam pemerintahan maupun sektor jasa lainnya ditentukan suasana dalam organisasi yang diciptakan oleh tata hubungan / komunikasi antar pribadi (interpersonal relationships) yang berlaku di lingkungan organisasi tersebut. Selain adanya komunikasi, motivasi juga merupakan hal yang akan mempengaruhi pegawai untuk melakukan tugasnya dalam rangka pencapaian kinerja pegawai. Dan yang tidak kalah pentingnya pemberian imbalan (reward), yang juga diyakini merupakan salah satu faktor yang mempengaruhi kinerja pegawai.

Berdasarkan beberapa substansi permasalahan yang peneliti uraikan di atas, maka dalam penelitian ini penulis tertarik untuk melakukan penelitian dengan judul "Pengaruh Komunikasi, Motivasi dan Imbalan Terhadap Kinerja Pegawai Sekretariat DPRD Provinsi Sumatera Selatan".
Berdasarkan latar belakang penelitian, maka dapat diidentifikasi masalah sebagai berikut komunikasi yang kurang berjalan dengan baik antar pegawai maupun dengan pimpinan, antara lain seringnya salah pengertian tentang pelaksanaan suatu tugas, motivasi pegawai yang masih rendah, hal ini tergambar dari tidak dilaksanakannya suatu tugas kalau tidak diingatkan dan/atau diperintahkan oleh pimpinan, reward atau imbalan yang ada tidak merata diterima oleh masing-masing pegawai di berbagai bidang tugas. Imbalan tertentu hanya diterima oleh pegawai yang tugasnya banyak berhubungan langsung dengan pimpinan dan anggota DPRD Provinsi Sumatera Selatan dan kinerja pegawai yang belum optimal, terlihat ada beberapa bagian yang belum dilaksanakan sesuai dengan yang diharapkan.

Berdasarkan beberapa pokok permasalahan yang berhasil diidentifikasi dalam penelitian ini, maka rumusan masalah yang akan dikaji dalam penelitian ini adalah apakah komunikasi mempunyai pengaruh yang signifikan terhadap kinerja pegawai, apakah motivasi mempunyai pengaruh yang signifikan terhadap kinerja pegawai, apakah imbalan mempunyai pengaruh yang signifikan terhadap kinerja pegawai dan apakah komunikasi, motivasi dan imbalan secara bersama-sama mempunyai pengaruh yang signifikan terhadap 
kinerja pegawai pada Sekretariat DPRD Provinsi Sumatera Selatan.

Adapun tujuan yang ingin dicapai peneliti dalam penelitian ini adalah untuk mengetahui apakah komunikasi mempunyai pengaruh yang signifikan terhadap kinerja pegawai, untuk mengetahui apakah motivasi mempunyai pengaruh yang signifikan terhadap kinerja pegawai, untuk mengetahui apakah imbalan mempunyai pengaruh yang signifikan terhadap kinerja pegawai dan untuk mengetahui apakah komunikasi, motivasi dan imbalan secara bersama-sama mempunyai pengaruh yang signifikan terhadap kinerja pegawai pada Sekretariat DPRD Provinsi Sumatera Selatan.

Manfaat yang diharapkan dari penelitian ini antara lain bagi pengembangan ilmu pengetahuan, maka pemilihan topik bahasan tentang faktor komunikasi, motivasi dan imbalan yang dikaitkan dengan kinerja, secara teoritis akan memberikan gambaran yang lebih konkrit dan dapat dijadikan sumber pijakan dalam menentukan implikasi kebijakan. Bagi kepentingan kedinasan, bahwa hasil penelitian ini dapat dijadikan input dalam penerapan pembinaan tata hubungan/komunikasi, pemberian motivasi dan imbalan kepada pegawai yang relatif tepat pada organisasi pemerintah dalam upaya meningkatkan kinerja pegawai.

\section{METODE PENELITIAN}

Populasi menurut Sugiyono (2002 : 57) adalah wilayah generalisasi yang ditetapkan oleh penelitian untuk dipelajari dan kemudian ditarik kesimpulan. Populasi juga sebagai kumpulan elemen yang mempunyai karakteristik tertentu yang sama dan mempunyai kesempatan yang sama untuk dipilih menjadi anggota sampel (Umar, 2003 : 136). Sementara Riduan (2005 : 54) mengatakan bahwa populasi adalah keseluruhan dari karakteristik atau niat hasil pengukuran yang menjadi objek penelitian.

Populasi dalam penelitian ini adalah seluruh Pegawai yang ada di lingkungan Sekretariat Dewan Perwakilan Rakyat Daerah Provinsi Sumatera Selatan sebanyak 111 orang, baik PNS yang berjumlah 71 orang PNS maupun Pegawai Honorer yang berjumlah 40 orang.

Umar (2003 : 141), mengatakan untuk menentukan berapa minimal sampel yang dibutuhkan jika diketahui, maka digunakan rumus Slovin, yaitu:

$$
\mathrm{n}=\frac{\mathrm{N}}{1+\mathrm{N} \mathrm{e}^{2}}
$$

Dimana:

$\mathrm{n}=$ ukuran sampel

$\mathrm{N}=$ ukuran populasi

$\mathrm{e}=$ kelonggaran ketidak telitian

karena kesalahan pengambilan sampel yang dapat ditolerir (5\%) 


\begin{tabular}{lcr}
\multicolumn{1}{c}{ Dengan } & melalui & proses \\
perhitungan & atas & dasar \\
pengelompokan & 111 & pegawai \\
menjadi 2 kelompok (71 PNS dan 40
\end{tabular}

Pegawai Honorer), maka sampel dalam penelitian ini sebanyak 78 pegawai. Dengan sistem proporsional, 78 pegawai sebagai sampel terdiri dari 49 PNS dan 28 pegawai honorer.

Metode penelitian yang digunakan dalam penelitian ini adalah metode survey yang bersifat kausalistik, yaitu dengan cara membagi variabel-variabel penelitian ke dalam variabel bebas dan variabel terkait.

Dalam metode penelitian survey ini, alat atau instrumen pengumpulan data yang digunakan adalah daftar pertanyaan (kuesioner) dan wawancara dengan responden terpilih. Kuesioner adalah salah satu teknik pengumpulan data melalui formulir-formulir yang berisi pertanyaan yang diajukan secara tertulis pada seseorang responden atau sekumpulan orang untuk mendapatkan jawaban atau tanggapan informasi atau data.

Alat analisis data yang digunakan dalam penelitian ini adalah:

\section{Analisis Deskriptif}

Analisis ini merupakan suatu analisis yang menguraikan data hasil penelitian tanpa melakukan pengujian analisis deskriptif ini disajikan dalam bentuk tabel frekwensi ini dilakukan dengan membuat kelompok atau nilai skor total dan jawaban responden.

2. Analisis Inferensial

Analisis ini untuk menguji lebih lanjut hipotesa penelitian yang telah dirumuskan sebelumnya, yaitu ada pengaruh yang signifikan antara komunikasi, motivasi dan imbalan, baik secara bersama-sama maupun sendiri-sendiri terhadap kinerja pegawai di lingkungan Sekretariat Dewan Perwakilan Rakyat Daerah Provinsi Sumatera Selatan.

Penelitian ini bertujuan untuk mencari pengaruh variabel-variabel komunikasi, motivasi dan imbalan terhadap kinerja pegawai pada Sekretariat Dewan Perwakilan Rakyat Daerah Provinsi Sumatera Selatan. Desain penelitiannya adalah desain kausal. Dengan demikian, analisis yang digunakan adalah analisis regresi linier berganda. Pengujian validitas dan reabilitas dilakukan dengan menguji batir-butir pernyataan yang ada dalam kuesioner, apakah isi dari butir-butir pernyataan tersebut sudah valid dan reliabel.

Prosedur yang dilakukan dalam pengujian validitas batir-butir pernyataan ádalah dengan menguji korelasi antara skor butir dengan skor total. Koefisien korelasi yang tinggi menunjukkan kesesuaian antara butir tes dengan tes secara keseluruhan. Prosedur ini disebut dengan validasi item menggunakan pendekatan internal consistency. 
Metode yang digunakan untuk mencari validitas butir pernyataan dalam kuesioner adalah validitas antara butir-butir (internal validity) yang dilakukan dengan cara mencari skor corrected item-total correlation atau melakukan perhitungan korelasi antara butir tes dengan skor total. Untuk menghitung korelasi tersebut diukur dengan teknik korelasi Product Moment.

Adapun rumus umum dari korelasi Product Moment [r] adalah sebagai berikut:

$$
r=\frac{\left.N\left(\sum X Y\right)-\sum X \sum Y\right)}{\sqrt{\left(N \sum X^{2}-\left(\sum X\right)^{2}\right)\left(N \sum Y^{2}-\left(\sum Y\right)^{2}\right)}}
$$

Keterangan:

$\mathrm{X}=$ skor tiap item

$\mathrm{Y} \quad=$ skor total tes-skor item

$\mathrm{N} \quad=$ jumlah subyek penelitian

Sedangkan metode yang digunakan untuk mendapatkan reliabilitas alat ukur juga menggunakan metode internal consistency, dengan mencari koefisien alpha Cronbach. Adapun rumus koefisien alpha Cronbach adalah sebagai berikut:

$r=\frac{k}{k-1} \frac{\left(1-\sum i^{2}\right)}{\tau^{2}} \operatorname{dim} a n a \longrightarrow i^{2}=\frac{\sum X i^{2}-\left(\sum X i\right)^{2} / N}{N}$

Keterangan:

$\mathrm{r}=$ koefisien reabiilitas yang dicari

$\mathrm{k}=$ jumlah butir pertanyaan [soal]

$i^{2}=$ varians butir-butir pertanyaan

[soal] atau varians butir pertanyaan ke-n

$=$ varians skor tes $\sum \mathrm{Xi}=$ jumlah skor jawaban subjek untuk butir pertanyaan ke-n

$\tau^{2} \quad$ Jika $\mathrm{r}$ alpha positif dan $\mathrm{r}$ alpha $>\mathrm{r}$ table, maka butir atau variable tersebut reabel. Pengujian terhadap validitas maupun reliabilitas skala dilakukan dengan bantuan Program SPSS.

Pengujian hipotesis dilakukan dengan uji statistik menggunakan motode regresi linier berganda karena variabel independen yang digunakan lebih dari satu variabel. Analisa regresi berganda digunakan untuk melihat pengaruh antara lebih dari satu variabel, yang dalam penelitian ini adalah komunikasi, motivasi dan imbalan terhadap kinerja pegawai pada Sekretariat Dewan Perwakilan Rakyat Daerah Provinsi Sumatera Selatan.

Adapun persamaan regresi bergandanya adalah:

$$
Y=a+b_{1} x_{1}+b_{2} x_{2}+b_{3} x_{3}+e
$$

Keterangan:

$\mathrm{Y}=$ Kinerja Pegawai

$\mathrm{A}=$ Konstanta

$b_{1}, b_{2}, b_{3}=$ Koefisien regresi

$\mathrm{x}_{1}=$ Variabel komunikasi

$\mathrm{x}_{2}=$ Variabel motivasi

$\mathrm{x}_{3}=$ Variabel imbalan

$\mathrm{e}=$ Error

Selanjutnya untuk menguji hipotesis digunakan persyaratan sebagai berikut:

Ho = tidak ada pengaruh yang signifikan dari komunikasi, 
motivasi dan imbalan secara bersama-sama maupun secara sendiri-sendiri terhadap kinerja pegawai di lingkungan Sekretariat Dewan Perwakilan Rakyat Daerah Provinsi Sumatera Selatan.

$\mathrm{Ha}=$ ada pengaruh yang signifikan dari komunikasi, motivasi dan imbalan secara bersama-sama maupun secara sendiri-sendiri terhadap kinerja pegawai di lingkungan Sekretariat Dewan Perwakilan Rakyat Daerah Provinsi Sumatera Selatan.

Untuk menguji koefisien regresi secara bersama-sama dengan menggunakan alat uji-F atau F-test dengan tahapan sebagai berikut :

1). Membuat formulasi hipotesis

Ho $=\beta_{1}=\beta_{2}=\beta_{3}=0$ (hipotesis nol)

Artinya tidak ada pengaruh yang signifikan dari variable independen Komunikasi $\left(\mathrm{X}_{1}\right)$, Motivasi $\left(\mathrm{X}_{2}\right)$ dan Imbalan $\left(\mathrm{X}_{3}\right)$ terhadap kinerja pegaw: $\left.\beta_{1} \mathrm{Y}\right) \cdot \beta_{2} \quad \beta_{3}$

$\mathrm{Ha} \mathrm{\#} \mathrm{\#} \mathrm{\#} \mathrm{\#} \mathrm{\#} 0$ (hipotesis alternatif)

Artinya ada pengaruh yang signifikan dari variable independen Komunikasi $\left(\mathrm{X}_{1}\right)$, Motivasi $\left(\mathrm{X}_{2}\right)$ dan Imbalan $\left(\mathrm{X}_{3}\right)$ terhadap Kinerja Pegawai (Y).

2). Menentukan level of significan

3). Menguji hipotesis

Uji Hipotesis yang dipergunakan adalah uji t dengan yang dicari dengan rumus:

$$
t_{1}=\frac{r_{x 1} \sqrt{n-2}}{\sqrt{1-r^{2} x 1}}
$$

Keterangan:

$r=$ Koefisien diterminasi

$\mathrm{n}=$ Jumlah sampel

$\mathrm{t}=$ Bila nilai sig untuk $\mathrm{t}<0,05$ maka

Ho ditolak dan Ha diterima

Sedangkan dalam pendugaan dalam simultan digunakan uji $\mathrm{F}$ dengan rumus sebagai berikut:

$\underset{\text { Keterang: }}{F}=\frac{\frac{R^{2} K}{\left(1-R^{2}\right)}}{(n-k-1)}$

$\mathrm{R}=$ Koefisien diterminasi

$\mathrm{K}=$ Jumlah variabel independen

$\mathrm{N}=$ Jumlah sampel

$\mathrm{F}=$ Bila nilai sig untuk $\mathrm{F}<0,05$

maka Ho ditolak dan Ha diterima

Untuk menjelaskan besarnya pengaruh nilai suatu variable (variable $\mathrm{x}$ ) terhadap naik/turunnya (variasi) nilai variable lainnya (variable y), maka perlu diketahui nilai koefisien diterminasi $\left[\mathrm{R}^{2}\right]$. adapun koefisiennya dirumuskan :

$$
R^{2}=\frac{(n)\left(\sum x\right)\left(\sum y\right)^{2}}{\left[(n)\left(\sum x^{2}\right)-\left(\sum X\right)^{2}\left(n\left(\sum Y^{2}\right)\left(\sum Y\right)^{2}\right]\right.}
$$

Kegunaan $\mathrm{R}^{2}$ adalah:

1. Sebagai ukuruan ketepatan suatu garis regresi yang diterapkan suatu kelompok data hasil survey, makin besar nilai adjusted $\mathrm{R}^{2}$ akan semakin tidak tepa $\alpha=5 \%$ egresi tersebut, untuk mewakili data hasil observasi. 
2. Untuk mengetahui besarnya proporsi atau prosentase dari jumlah variasi dari variable terkait.

3. Dalam pengolahan dan analisis data yang akan didapat akan dilakukan baik secara manual maupun dengan menggunakan bantuan komputer Program SPSS.

HASIL PENELITIAN DAN PEMBAHASAN

Hasil Penelitian

Karakteristik Responden

Tabel 1. Distribusi Responden berdasarkan Jenis Kelamin

\begin{tabular}{|ll|r|r|r|r|}
\hline & \multicolumn{1}{|c|}{$\begin{array}{c}\text { Frequenc } \\
\text { y }\end{array}$} & \multicolumn{1}{c|}{ Percent } & Valid Percent & $\begin{array}{c}\text { Cumulativ } \\
\text { e Percent }\end{array}$ \\
\hline Valid & Laki-laki & 44 & 56,4 & 56,4 & 56,4 \\
& Perempuan & 34 & 43,6 & 43,6 & 100,0 \\
& Total & 78 & 100,0 & 100,0 & \\
\hline
\end{tabular}

Sumber : Data Primer

Tabel 1 diatas menunjukkan bahwa subyek penelitian berjenis kelamin orang sedangkan yang berjenis laki-laki $56,4 \%$ atau sebanyak 44

kelamin perempuan berjumlah $43,6 \%$ orang atau sebanyak 34 orang.

Tabel 2. Distribusi Responden Berdasarkan Tingkat Pendidikan

\begin{tabular}{|l|r|r|r|r|}
\hline & Frequency & Percent & $\begin{array}{c}\text { Valid } \\
\text { Percent }\end{array}$ & Cumulative Percent \\
\hline SD & 0 & 0 & 0 & 0 \\
SLTP & 3 & 3,9 & 3,9 & 3,9 \\
SLTA & 45 & 57,7 & 57,7 & 61,6 \\
Diploma & 10 & 12,7 & 12,7 & 74,3 \\
S1 & 17 & 21,8 & 21,8 & 96,1 \\
S2 & 3 & 3,9 & 3,9 & 100,0 \\
S3 & 0 & 0 & 0 & 100,0 \\
\hline Total & $\mathbf{7 8}$ & $\mathbf{1 0 0 , 0}$ & $\mathbf{1 0 0 , 0}$ & \\
\hline
\end{tabular}

\section{Sumber : Data Primer}

Tabel 2 tersebut di atas menunjukkan bahwa pendidikan terendah subyek penelitian adalah Tingkat SLTP sebesar 3,9\% atau 3 orang dan yang tertinggi Sarjana Strata 2 sebesar $3,9 \%$ atau 3 orang. Sedangkan sebagian besar sebagai Subjek penelitian berpendidikan SLTA sebanyak $57,5 \%$ (45 orang) dan Sarjana Strata 1 sebesar $17 \% \quad(17$ orang). 
Tabel 3. Karakteristik Responden Berdasarkan Status Kepegawaian

\begin{tabular}{|lr|r|r|r|r|}
\hline & & Frequency & Percent & $\begin{array}{c}\text { Valid } \\
\text { Percent }\end{array}$ & Cumulative Percent \\
\hline Valid & HONORER & 28 & 35,9 & 35,9 & 35,9 \\
& & 50 & 64,1 & 64,1 & 100,0 \\
& & & \\
& Total & 78 & 100,0 & 100,0 & \\
\hline
\end{tabular}

Sumber : Data Primer

Tabel 3 tersebut di atas menunjukkan bahwa status pegawai di lingkungan dan Sekretariat DPRD Provinsi Sumatera Selatan adalah Pegawai Negeri Sipil (PNS) sebesar 35,9\% (28 orang) dan yang berstatus sebagai Pegawai Honorer sebanyak 50 orang atau $64,1 \%$.

\section{Analisis Data}

\section{Uji Validitas}

Telah dijelaskan pada Bab sebelumnya bahwa kuesioner yang digunakan sebagai instrumen penelitian terlebih dulu diuji validitas dan reliabilitasnya. Uji validitas instrumen bertujuan untuk mengetahui sejauh mana ketepatan dan kecermatan alat ukur dalam melakukan fungsi ukurannya, menggunakan rumus statistika koefisien korelasi Rank Spearman, Hasil uji validitas untuk variabel Komunikasi, Motivasi, Imbalan dan Kinerja Pegawai.

Dari perhitungan uji validitas dinyatakan bahwa nilai korelasi setiap item dari masing-masing variable terhadap koefisien (r) lebih besar dari 0,220 hal tersebut berarti bahwa data Komunikasi, Motivasi, dan Imbalan yang didapatkan adalah valid sekalipun ada beberapa item pernyataan harus dieliminir untuk beberapa variabel.

\section{Uji Reliabilitas}

Sedangkan untuk pengujian reliabilitas atas instrumen yang sama digunakan formula Spearman Brown. Formula ini digunakan untuk melihat sejauh mana alat ukur dapat memberikan hasil yang relatif tidak bebeda bila dilakukan pengukuran kembali terhadap gejala yang sama pada saat yang berbeda. Jadi, pengukuran reliabilitas berkenaan dengan konsistensi dan keakuratan pengukuran.

Untuk mengetahui reliabilitas data yang diperoleh, dilihat dari nilai Cronbach Alpha setiap variabel yang dibandingkan dengan nilai koefisien yang telah didtetapkan. Dari hasil pengolahan data primer dengan menggunakan aplikasi komputer SPSS, nilai tersebut direkapitulasi dalam tabel 4 berikut ini : 
Tabel 4. Rekapitulasi Hasil Uji Reliabilitas

\begin{tabular}{|l|c|l|}
\hline \multicolumn{1}{|c|}{ Variabel } & Nilai Cronbach Alpha & Ket \\
\hline Komunikasi &, 957 & Reliabel \\
\hline Motivasi &, 792 & Reliabel \\
\hline Imbalan &, 769 & Reliabel \\
\hline Kinerja &, 946 & Reliabel \\
\hline \multicolumn{2}{|c|}{ Sumber : ringkasan Hasil Pengolahan data primer menggunakan SPSS) }
\end{tabular}

Nilai-nilai pada tabel 4 di atas untuk masing masing variabel penelitian, semuanya mendekati angka 1 . hal tersebut menunjukkan bahwa reliabiltas instrumen penelitian yang diujikan adalah handal, hal itu juga berarti bahwa alat ukur yang digunakan apabila diukur atau dipakai secara berulang tidak akan mengalami perubahan dan akan memberikan hasil yang serupa.

\section{Analisis Regresi Linier Berganda}

\section{Uji Persyaratan Untuk Normalitas}

Tujuan dilakukannya uji normalitas adalah untuk mengetahui apakah model regresi dalam penelitian ini variabel terikat dan variabel bebas keduanya mempunyai distribusi normal atau tidak. Model regresi yang baik adalah memiliki distribusi data normal atau mendekati normal. Data yang berdistribusi normal dalam suatu model regresi dapat dilihat pada grafik normal P-P plot, dimana bila titik-titik yang menyebar disekitar garis diagonal serta penyebarannya mengikuti arah garis diagonal, maka data tersebut dapat dikatakan berdistribusi normal. Pada Gambar 4.1 memperlihatkan P-P Plot dari pengumpulan data menunjukkan berdistribusi normal.

Dari gambar 1 di bawah ini terlihat bahwa penyebaran data mendekati garis diagonal yang berarti bahwa data penelitian ini memiliki distribusi normal.

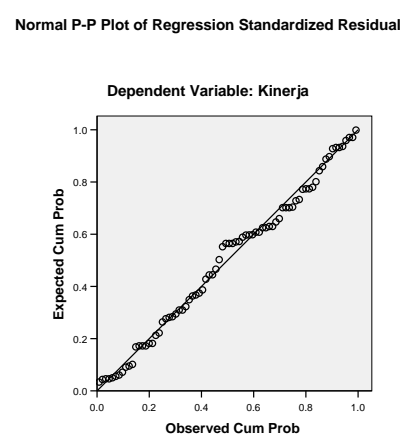

Gambar 1 P-P Plot dari pengumpulan data

\section{Hasil Analisis Regresi Linier Berganda}

Dengan perhitungan statistik menggunakan aplikasi SPSS dimana data yang didapat tersebut telah diketahui berdistribusi normal, maka berikut ini adalah uraian analisis untuk perhitungan statistik tersebut.

\section{a. Korelasi}

Berdasarkan hasil analisis menggunakan SPSS yang ditampilkan seperti pada table 5 . berikut ini : 
Tabel 5. Rekapitulasi Hasil Uji Korelasi

\begin{tabular}{|ll|r|r|r|r|}
\hline & & Kinerja & Komunikasi & Motivasi & Imbalan \\
\hline Pearson & Kinerja & 1,000 &, 874 &, 584 &, 080 \\
Correlation & &, 874 & 1,000 &, 668 &, 125 \\
& Komunikasi &, 584 &, 668 & 1,000 &, 486 \\
& Motivasi &, 080 &, 125 &, 486 & 1,000 \\
& Imbalan &, 000 &, 000 &, 243 \\
Sig. (1-tailed) & Kinerja &, 000 &, 000 &, 138 \\
& Komunikasi &, 000 &, 000 &. &, 000 \\
& Motivasi &, 243 &, 138 &, 000 & \\
& Imbalan & 78 & 78 & 78 & 78 \\
& Kinerja & 78 & 78 & 78 & 78 \\
& Komunikasi & 78 & 78 & 78 & 78 \\
& Motivasi & 78 & 78 & 78 & 78 \\
\hline
\end{tabular}

Sumber : Ringkasan Hasil Pengolahan data primer menggunakan SPSS)

Berdasarkan table 5 diatas dijelaskan bahwa dengan jumlah sample 78 data menghasilkan koefisien korelasi sebesar $\mathbf{0 . 8 7 4}$ antara variable Kinerja dan Komunikasi, artinya terdapat hubungan yang kuat antara kedua variable tersebut. Besaran ini dapat dibuktikan dengan taraf signifikan $0,000<0,05$; hal ini berarti terdapat hubungan yang signifikan antara Kinerja dengan Komunikasi.
Berdasarkan hasil analisis menggunakan SPSS yang ditampilkan seperti pada table 6 . berikut ini :

\section{b. Model Summary}

Tabel 6. Model Summary

\begin{tabular}{|c|c|c|c|c|c|c|c|c|c|}
\hline \multirow[t]{2}{*}{ Model } & \multirow[t]{2}{*}{$\mathbf{R}$} & \multirow{2}{*}{$\begin{array}{c}\mathbf{R} \\
\text { Squar } \\
\mathbf{e}\end{array}$} & \multirow{2}{*}{$\begin{array}{l}\text { Adjusted } \\
\text { R Square }\end{array}$} & \multirow{2}{*}{$\begin{array}{c}\text { Std. Error } \\
\text { of the } \\
\text { Estimate }\end{array}$} & \multicolumn{5}{|c|}{ Change Statistics } \\
\hline & & & & & $\begin{array}{c}\mathrm{R} \\
\text { Square } \\
\text { Chang } \\
\mathrm{e}\end{array}$ & $\begin{array}{c}\text { F } \\
\text { Chang } \\
\text { e }\end{array}$ & df1 & df 2 & $\begin{array}{l}\text { Sig. F } \\
\text { Chang } \\
\text { e }\end{array}$ \\
\hline 1 &, $875(a)$ & ,766 & ,756 & ,22645 & ,766 & 80,679 & 3 & 74 &, 000 \\
\hline 2 & ,875(b) & ,765 & ,759 & ,22510 &, 000 & ,113 & 1 & 74 & ,738 \\
\hline 3 &, $874(c)$ & ,765 & ,762 & 22402, &,- 001 & ,272 & 1 & 75 & ,603 \\
\hline
\end{tabular}

a Predictors: (Constant), Imbalan, Komunikasi, Motivasi

b Predictors: (Constant), Imbalan, Komunikasi 
Dari table 4.21 tersebut di atas, dapat dinyatakan bahwa :

1. Hubungan Komunikasi (X1), Motivasi (X2) dan Imbalan (X3) terhadap Kinerja pegawai (Y)

a. Nilai koefisien korelasi (R) sebesar 0,875 yang berarti bahwa terdapat hubungan yang kuat antara variabel Komunikasi (X1), Motivasi (X2), dan Imbalan (X3), serta memiliki arah yang positif dengan variabel Kinerja (Y).

b. Diperlihatkan juga dalam tabel 4.21. tersebut bahwa koefisien determinasi $\left(\mathrm{R}^{2}\right)$ sebesar 0,766. Besaran tersebut menunjukkan bahwa kemampuan variabel Komunikasi (X1), Motivasi (X2), dan Imbalan (X3) dapat menjelaskan sebesar 76,6 \% untuk variansi pada variabel terikat Kinerja (Y), sedangkan selebihnya atau sebesar 23,4\% dipengaruhi oleh faktor lain yang tidak diikutsertakan dalam penelitian ini.

2. Hubungan Komunikasi (X1) dan Imbalan (X3) terhadap Kinerja pegawai (Y)

a. Nilai koefisien korelasi (R) sebesar 0,875 yang berarti bahwa terdapat hubungan yang kuat antara variabel Komunikasi (X1) dan Imbalan (X3), serta memiliki arah yang positif dengan variabel Kinerja (Y). b. Diperlihatkan juga dalam tabel 4.21. tersebut bahwa koefisien determinasi $\left(\mathrm{R}^{2}\right)$ sebesar 0,765 . Besaran tersebut menunjukkan bahwa kemampuan variabel Komunikasi (X1) dan Imbalan (X3) dapat menjelaskan sebesar 76,5\% untuk variansi pada variabel terikat Kinerja (Y), sedangkan selebihnya atau sebesar 23,5\% dipengaruhi oleh faktor lain yang tidak diikutsertakan dalam penelitian ini.

3. Hubungan Komunikasi (X1) terhadap Kinerja pegawai (Y)

a. Nilai koefisien korelasi (R) sebesar 0,874 yang berarti bahwa terdapat hubungan yang kuat antara variabel Komunikasi (X1) dan Kinerja pegawai (Y) serta memiliki arah yang positif.

b. Diperlihatkan juga dalam tabel 6 tersebut bahwa koefisien determinasi $\left(\mathrm{R}^{2}\right)$ sebesar 0,765. Besaran tersebut menunjukkan bahwa kemampuan variabel Komunikasi (X1) dapat menjelaskan sebesar 76,5 \% untuk variansi pada variabel terikat Kinerja (Y), sedangkan selebihnya atau sebesar $23,5 \%$ dipengaruhi oleh faktor lain yang tidak diikutsertakan dalam penelitian ini.

\section{c. Anova (Analysis Of Variance)}

Dalam menyatakan apakah variabel-variabel bebas yang diteliti 
berpengaruh signifikan atau tidak signifikan terhadap variabel terikat, peneliti mengikuti kriteria menggunakan signifikansi $\mathrm{F}$ yakni membandingkan signifikansi $\mathrm{F}$ hitung dengan nilai alpha yang ditetapkan sebesar 5\% $(\alpha=0,05)$ dalam menjelaskan koefisien $\mathrm{F}$ garis regresi dalam penelitian ini.

Tabel 7. ANOVA

\begin{tabular}{|l|l|r|r|r|c|c|}
\hline Model & & Sum of Squares & df & Mean Square & F & Sig. \\
\hline 1 & Regression & 12,411 & 3 & 4,137 & 80,679 &, $000(\mathrm{a})$ \\
& Residual & 3,795 & 74 &, 051 & & \\
& Total & 16,206 & 77 & & & \\
2 & Regression & 12,405 & 2 & 6,203 & 122,409 &, $000(\mathrm{~b})$ \\
& Residual & 3,800 & 75 &, 051 & & \\
& Total & 16,206 & 77 & & & \\
3 & Regression & 12,392 & 1 & 12,392 & 246,910 &, $000(\mathrm{c})$ \\
& Residual & 3,814 & 76 &, 050 & & \\
& Total & 16,206 & 77 & & & \\
\hline
\end{tabular}

a Predictors: (Constant), Imbalan, Komunikasi, Motivasi

b Predictors: (Constant), Imbalan, Komunikasi

c Predictors: (Constant), Komunikasi

d Dependent Variable: Kinerja

Seperti terlihat pada table $7 \mathrm{di}$ atas, signifikansi $\mathrm{F}$ bernilai $0,00(\mathrm{p}-$ Value $<0,05)$ artinya adalah dengan penjelasan garis regresi menggunakan data yang terkumpul dapat dinyatakan bahwa koefisien regresi ganda variabel Komunikasi (X1), Motivasi (X2), dan Imbalan (X3) berpengaruh signifikan terhadap variabel Kinerja (Y). Selanjutnya berdasarkan penghitungan taraf signifikansi $\mathrm{F}$ $0,000<0,05$, maka secara simultan terdapat pengaruh yang nyata dari variable bebas terhadap variable terikat.

\section{d. Coefficients}

Besarnya koefisien beta dengan analisis menggunakan regresi linier berganda dapat dilihat pada gambar berikut : 
Tabel 8. Coefficients

\begin{tabular}{|c|c|c|c|c|c|c|}
\hline \multirow[t]{2}{*}{ Model } & & \multicolumn{2}{|c|}{$\begin{array}{l}\text { Unstandardized } \\
\text { Coefficients }\end{array}$} & \multirow{2}{*}{$\begin{array}{l}\text { Standardized } \\
\text { Coefficients } \\
\text { Beta }\end{array}$} & \multirow[t]{2}{*}{$\mathrm{t}$} & \multirow[t]{2}{*}{ Sig. } \\
\hline & & B & Std. Error & & & \\
\hline \multirow[t]{4}{*}{1} & (Constant) &, 430 & ,283 & & 1,519 & ,133 \\
\hline & Komunikasi & ,792 & 073 & ,859 & 10,813 &, 000 \\
\hline & Motivasi &, 055 &, 164 & ,030 & ,336 & ,738 \\
\hline & Imbalan &,- 086 &, 140 &,- 042 &,- 618 & ,538 \\
\hline \multirow[t]{3}{*}{2} & (Constant) & ,469 & ,258 & & 1,817 & ,073 \\
\hline & Komunikasi & ,809 &, 052 & ,878 & 15,581 &, 000 \\
\hline & Imbalan &,- 061 & ,116 &,- 029 &,- 522 & ,603 \\
\hline \multirow[t]{2}{*}{3} & (Constant) & ,363 &, 158 & & 2,292 & ,025 \\
\hline & Komunikasi & ,806 &, 051 & 874 & 15,713 & ,000 \\
\hline
\end{tabular}

Sumber : Hasil Pengolahan data primer menggunakan SPSS)

Berdasarkan output pada table 8 di atas, dari nilai pada kolom Unstandardized Coefficients dan kolom B, didapat nilai constant sebesar $=\mathbf{0 , 4 3 0}$. nilai koefisien variabel Komunikasi $=\mathbf{0 , 7 9 2}$, Motivasi $=\mathbf{0 , 0 5 5}$, dan Imbalan = 0,086.

Bila variabel motivasi (X2) dihilangkan (removed) dengan metode stepwise yang dikarenakan motivasi mempunyai pengaruh tetapi tidak signifikan terhadap kinerja pegawai (Y) maka dapat dilihat pada kolom Unstandardized Coefficients dan kolom B, didapat nilai constant sebesar $=\mathbf{0 , 4 6 9}$. nilai koefisien variabel Komunikasi $=\mathbf{0 , 8 0 9}$, dan Imbalan = - 0,061.

Sedangkan bila variabel motivasi (X2) dan imbalan (X3) dihilangkan (removed) dengan metode stepwise yang dikarenakan imbalan tidak mempunyai pengaruh yang signifikan terhadap kinerja pegawai (Y) maka dapat dilihat pada kolom Unstandardized Coefficients dan kolom B, didapat nilai constant sebesar $=\mathbf{0 , 3 6 3}$ dan nilai koefisien variabel Komunikasi $=\mathbf{0 , 8 0 6}$.

Dari nilai-nilai tersebut yang digunakan untuk membuat persamaan garis regresi dalam penelitian ini adalah besaran koefisien beta, dimana persamaannya (rumusan persamaan garis regresi telah peneliti sampaikan dapat dinyatakan sebagai berikut :

$\mathrm{Y}=0,363+\mathbf{0 , 8 0 6} \mathrm{X} 1+\mathrm{e}$

Dimana $\mathrm{X} 1$ = variabel Komunikasi; dan $\mathrm{Y}=$ Kinerja.

Pembahasan untuk persamaan regresi tersebut dapat dibuat sebagai berikut:

- Nilai Y = 0,363; berarti bahwa jika nilai Komunikasi (X1), Motivasi (X2) ; Imbalan (X3) sama dengan NOL, maka kinerja akan bernilai 0,363 . 
- Nilai koefisien X1 = $\mathbf{0 , 8 0 6}$; berarti bahwa jika nilai Komunikasi berubah sebesar 1 satuan skor, maka nilai kinerja juga akan berubah sebesar $=\mathbf{0 , 8 0 6}$.

Sedangkan untuk uji t (t-Test) / Uji Parsial dengan menggunakan hasil analisis tersebut yang telah diolah dengan aplikasi paket program Statistical Program for Social Science (SPSS), seperti tertera pada table 4.23. maka dapat diuraikan sebagai berikut :

\section{Pengaruh Komunikasi (X1)} terhadap Kinerja (Y)

Nilai t hitung Komunikasi (X1), sebesar 10,813 dengan PV $\mathbf{0 , 0 0 0}$ (P-Value < 0.05). Dengan demikian terjadi penolakan Ho yang berarti menunjukkan adanya pengaruh yang signifikan antara variabel Komunikasi (X1) terhadap variabel Kinerja (Y).

\section{Pengaruh Motivasi}

(X2)

terhadap Kinerja (Y)

Nilai $\mathrm{t}$ hitung Motivasi (X2), sebesar 0,336 dengan tingkat signifikan sebesar $\mathbf{0 , 7 3 8}$ (P-Value $0,738>0.05)$. Dengan demikian terjadi penerimaan Ho yang berarti menunjukkan adanya pengaruh tetapi tidak signifikan antara variabel Motivasi (X2) terhadap variabel Kinerja (Y).

\section{Pengaruh Imbalan}

\section{terhadap Kinerja (Y)}

Nilai $\mathrm{t}$ hitung Imbalan (X3), sebesar -,618 dengan tingkat signifikan sebesar $\mathbf{0 , 5 3 8}$ (P-Value
$0,538>0.05)$. Dengan demikian terjadi penerimaan Ho yang berarti menunjukkan tidak adanya pengaruh yang signifikan antara Imbalan (X3) terhadap variabel Kinerja (Y).

\section{PEMBAHASAN}

Pembahasan yang akan dilakukan berikut ini berdasarkan hasil analisis statistik korelasi parsial, hubungan korelasional dan korelasi regresi linier berganda serta upaya pendalaman tiap variabel dengan menggunakan hasil analisis yang telah dioleh dengan bantuan paket program Statistical Program for Social Science (SPSS) for MS Windows Release 14.00.

1. Pengaruh Komunikasi Terhadap Kinerja

Nilai $\mathrm{t}$ hitung Komunikasi (X1), sebesar 10,813 dengan PV 0,000 (PValue < 0.05). Dengan demikian terjadi penolakan Ho yang berarti menunjukkan adanya pengaruh yang signifikan antara variabel Komunikasi (X1) terhadap variabel Kinerja (Y). Hal ini sejalan dengan pendapat Robbins (2006:392) bahwa komunikasi memperkuat motivasi dengan menjelaskan ke para karyawan apa yang harus dilakukan, seberapa baik mereka bekerja, dan apa yang dapat dikerjakan untuk memperbaiki kinerja yang di bawah standar.

Seiring dengan pelaksanaan otonomi daerah, komunikasi menjadi sangat penting untuk membantu 
memecahkan masalah-masalah yang kompleks dan dimana masingmasing individu diharapkan dapat senantiasa terlibat dalam pengambilan keputusan. Dengan menjadi pendengar yang baik dan mendorong bawahan mengadakan komunikasi selengkapnya, maka pimpinan akan mempunyai kesempatan yang lebih baik untuk memperoleh jenis informasi yang diperlukan.

Para pegawai di lingkungan Sekretariat DPRD Provinsi Sumatera Selatan setidaknya harus menjalin komunikasi yang baik dengan pimpinan dan sesama rekan kerja, sehingga dalam melaksanakan tugas hasil yang diperoleh sesuai dengan apa yang diharapkan. Pada akhirnya melalui komunikasi yang baik akan mempengaruhi kinerja para pegawai di kantor, seperti yang dikatakan Davis (1996 : 112) bahwa komunikasi organisasi adalah suatu sistem yang saling tergantung yang mencakup komunikasi internal dan komunikasi eksternal. Komunikasi internal antara lain komunikasi dalam organisasi seperti komunikasi dari bawahan ke atasan, komunikasi dari atasan ke bawahan dan komunikasi sesama pegawai/karyawan.

\section{Pengaruh Motivasi Terhadap Kinerja}

Nilai t hitung Motivasi (X2), sebesar 0,336 dengan tingkat signifikan sebesar $\mathbf{0 , 7 3 8}$ (P-Value
$0,738>0.05)$. Dengan demikian terjadi penerimaan Ho yang berarti menunjukkan adanya pengaruh tetapi tidak signifikan antara variabel Motivasi (X2) terhadap variabel Kinerja (Y).

Robins mengatakan bahwa kinerja karyawan adalah sebagai fungsi dari interaksi antar kemampuan dan motivasi, jika ada yang tidak memadai, kinerja itu akan dipengaruhi secara negatif. Kesempatan untuk berkinerja yang diartikan sebagai tingkat-tingkat kinerja yang tinggi sebagian merupakan fungsi dari absennya rintangan-rintangan yang mengendalikan seorang karyawan. Adapun rintangan yang mengendalai kinerja berupa lingkungan kerja yang kurang mendukung, peralatan, bahan, suplai yang kurang memadai, rekan kerja dan prosedur yang kurang mendukug (Robins, 1996 : 218).

Berdasarkan hasil penelitian penulis di atas, ternyata motivasi di kalangan pegawai Sekretariat DPRD Provinsi Sumatera Selatan tidak mempunyai pengaruh yang signifikan terhadap kinerja. Memang motivasi tidak menjadi satu-satunya faktor yang mempengaruhi kinerja, tentu ada faktor lainnya di luar motivasi.

Stonner (1996 : 134) menyampaikan bahwa di samping motivasi, penting juga faktor-faktor lain seperti kemampuan, sumber daya dan kondisi tempat kerja dalam 
melaksanakan pekerjaan tersebut. Seorang pegawai mungkin mempunyai motivasi kerja yang cukup tinggi untuk menyelesaikan pekerjaannya, tetapi pada motivasi seperti itu harus ditambahkan kemampuan ilmiah, seperti menganalisa suatu pekerjaan yang perlu pemikiran, mengoperasionalkan perangkat komputer, kemudian fasilitas kerja yang memadai seperti mesin tik, komputer dan fasilitas lan, selain kondisi seperti dapat menghubungi atasan dengan mudah dan juga harus kondusif.

Berdasarkan Profil

Kelembagaan Sekretariat DPRD Provinsi Sumatera Selatan tersebut di atas memang diakui bahwa adanya motivasi kerja staff Sekretariat DPRD Provinsi Sumatera Selatan terhadap rencana yang sudah disusun. Namun ternyata salah satu tantangannya adalah rendahnya mutu sumber daya manusia dan tingkat disiplin serta kesejahteraan pegawai Sekretariat DPRD Provinsi Sumatera Selatan. Ini juga tentunya menjadi salah satu indikator lainnya sebagai penyebab mengapa motivasi tidak mempunyai pengaruh yang signifikan terhadap kinerja para pegawai.

Ternyata dari jawaban-jawaban kuesioner yang diberikan sebagian pegawai Sekretariat DPRD Provinsi Sumatera Selatan dalam penelitian ini terungkap bahwa kebutuhankebutuhan dasar seperti di atas (pendidikan dan latihan, penghargaan atas prestasi, promosi jabatan dan gaji) belum/tidak pernah mereka tarima.

Hal ini juga membuktikan bahwa salah satu permasalahan di Sekretariat DPRD Provinsi Sumatera Selatan yang peneliti sampaikan pada pendahuluan memang terbukti bahwa motivasi pegawai yang masih rendah, hal ini tergambar dari tidak dilaksanakannya suatu tugas kalau tidak diingatkan dan/atau diperintahkan oleh pimpinan.

\section{Pengaruh Imbalan Terhadap} Kinerja

Nilai t hitung Imbalan (X3), sebesar -,618 dengan tingkat signifikan sebesar 0,538 (P-Value $0,538>0.05)$. Dengan demikian terjadi penerimaan Ho yang berarti menunjukkan tidak adanya pengaruh yang signifikan antara Imbalan (X3) terhadap variabel Kinerja (Y).

Ini berarti imbalan-imbalan yang diterima oleh pegawai Sekretariat DPRD Provinsi Sumatera Selatan tidak mempunyai pengaruh yang signifikan terhadap kinerja mereka.

Memang penentuan imbalan bagi seorang yang bekerja di institusi pemerintah (baik yang berstatus PNS maupun honorer) merupakan kebijakan pemerintah melalui APBN dan/atau APBD. Namun demikian pimpinan diharapkan mampu mencari langkah kreatif untuk tambahan imbalan terhadap pegawai 
, khususnya pegawai dengan tingkat rendah. Sekali lagi yang peneliti maksudkan imbalan tidak saja yang bersifat materi (ekstrinsik), tapi imbalan dalam bentuk bukan materi lainnya (intrinsik). Hal ini dilakukan untuk senantiasa mendukung usaha memperkecil kesenjangan antara pegawai dengan atasannya.

Dari jawaban-jawaban kuesioner yang diberikan sebagian pegawai Sekretariat DPRD Provinsi Sumatera Selatan dalam penelitian ini terungkap bahwa imbalanimbalan seperti tersebut di atas yang sebenarnya sangat dibutuhkan pegawai, ternyata tidak pernah mereka tarima. Hal ini tentunya akan mempengaruhi kinerja pegawai itu sendiri.

Hal ini juga membuktikan bahwa salah satu permasalahan di Sekretariat DPRD Provinsi Sumatera Selatan yang peneliti sampaikan pada pendahuluan memang terbukti bahwa reward atau imbalan yang ada tidak merata diterima oleh masingmasing pegawai di berbagai bidang tugas. Imbalan tertentu hanya diterima oleh pegawai yang tugasnya banyak berhubungan langsung dengan pimpinan dan anggota DPRD Provinsi Sumatera Selatan.

Sebagaimana disebutkan di atas bahwa salah satu tantangan Sekretariat DPRD Provinsi Sumatera Selatan adalah rendahnya mutu sumber daya manusia dan tingkat disiplin serta kesejahteraan pegawai. Masalah rendahnya kesejahteraan pegawai berhubungan langsung dengan imbalan yang mereka tarima. Ini tentunya menjadi salah satu penyebab mengapa imbalan tidak mempunyai pengaruh yang signifikan terhadap kinerja para pegawai.

4. Pengaruh Komunikasi, Motivasi dan Imbalan Terhadap Kinerja

Dengan mengambil taraf signifikan sebesar $5 \%$ maka dengan tingkat signifikan sebesar $0,000(\mathrm{p}<$ 0,05) maka Ho ditolak dan $\mathrm{Ha}$ diterima. Artinya secara bersama (simultan) dapat disimpulkan bahwa ada pengaruh yang signifikan antara komunikasi (X1), motivasi(X2) dan imbalan (X3) terhadap kinerja pegawai (Y).

Robbins

(2006:392)

berpendapat bahwa komunikasi memperkuat motivasi dengan menjelaskan ke para karyawan apa yang harus dilakukan, seberapa baik mereka bekerja, dan apa yang dapat dikerjakan untuk memperbaiki kinerja yang di bawah standar.

Sedangkan motivasi yang dimiliki seseorang akan terdorong melakukan suatu kegiatan untuk mencapai tujuannya. Kinerja (perfomance) dipengaruhi oleh tiga faktor yaitu faktor individual yang terdiri dari kemampuan dan keahlian, latar belakang dan demografi. Faktor psikologis yang terdiri dari persepsi, attitude, personality, pembelajaran dan motivasi. Faktor organisasi yang terdiri dari sumber daya, kepemimpinan, penghargaan, 
struktur dan job design (Simamora, 1995: 500).

Reward juga merupakan bagian penting dalam proses pencapaian dan peningkatan kinerja pegawai dalam suatu instansi atau perusahaan. Gitosudarmo (2000:234) mengatakan bahwa diyakini bahwa imbalan akan memotivasi prestasi, mengurangi perputaran tenaga kerja, mengurangi kemangkiran dan menarik pencari kerja yang berkualitas dalam organisasi.

Secara parsial memang motivasi (X2) dan imbalan (X3) tidak mempunyai pengaruh yang signifikan terhadap kinerja pegawai (Y). Selain dikarenakan sebab-sebab di atas sebagai penyebab tidak mempunyai pengaruh yang signifikan, peneliti ingin menyampaikan satu kemungkinan yang bisa jadi mempengaruhi para responden (pegawai) dalam mengisi angket.

Pada saat peneliti menyebarkan kuesioner kepada pegawai sebagai responden, dalam waktu yang bersamaan kondisi psikologis pegawai sedang cemas, gundah gulana dan berduka. Beberapa hari sebelumnya di berbagai media massa mengangkat kasus "rekayasa perampokan uang SILPA Sekretariat DPRD Sumsel, lebih kurang 300 juta". Apalagi otak pelaku sebagai bendaharawan Sekretariat DPRD Provinsi Sumsel telah ditahan polisi dan berjanji akan membongkar kebobrokan DPRD dari tahun 2002, 2003 dan 2004. Kemelut ini telah membuat kekhawatiran dan kecemasan tersendiri di lingkungan Sekretariat DPRD Provinsi Sumatera Selatan, tidak terkecuali dengan para pegawai (baik PNS maupun honorer).

\section{SIMPULAN DAN SARAN}

Berdasarkan analisis di atas tentang hubungan pengaruh Komunikasi (X1), Motivasi (X2) dan Imbalan (X3) terhadap Kinerja Pegawai (Y) pada Sekretariat Dewan Perwakilan Rakyat Daerah Provinsi Sumatera Selatan, berikut disajikan beberapa kesimpulan hasil dari kegiatan penelitian, disamping itu pula pada bab ini akan disajikan saran-saran sebagai alternatif solusi permasalahan.

\section{Kesimpulan}

1. Secara Parsial Komunikasi berpengaruh dan sangat signifikan terhadap kinerja, apabila ada peningkatan dalam komunikasi maka kinerja akan meningkat. Selanjutnya hipotesis yang menyatakan komunikasi secara parsial berpengaruh yang signifikan terhadap kinerja terbukti.

1. Secara Parsial Motivasi berpengaruh tetapi tidak signifikan terhadap kinerja. Selanjutnya hipotesis yang menyatakan motivasi secara parsial berpengaruh yang 
signifikan terhadap kinerja tidak terbukti.

2. Secara Parsial Imbalan tidak berpengaruh dan tidak signifikan terhadap kinerja. Selanjutnya hipotesis yang menyatakan imbalan secara parsial berpengaruh yang signifikan terhadap kinerja tidak terbukti.

3. Secara bersama-sama Komunikasi, Motivasi dan Imbalan mempunyai pengaruh yang signifikan terhadap kinerja, hal ini mengandung makna bahwa apabila ada peningkatan Komunikasi, Motivasi dan Imbalan maka kinerja akan meningkat.

\section{Saran}

Dari hasil penelitian dan kesimpulan yang telah disampaikan di atas dapat disampaikan beberapa saran, antara lain :

1. Hasil penelitian menunjukkan bahwa terdapat pengaruh yang nyata dan sangat signifikan antara komunikasi, motivasi dan imbalan terhadap kinerja. Dengan demikian agar dapat mencapai kinerja sesuai dengan yang diharapkan, para pimpinan di lingkungan Sekretariat DPRD Provinsi Sumatera Selatan diharapkan dapat terus menjalin komunikasi yang baik sehingga terjadinya hubungan baik dan kejelasan dalam menjalankan tugas. Hal ini dibuktikan bahwa dari hasil penelitian faktor komunikasi memiliki pengaruh yang paling besar terhadap kinerja pegawai.

2. Berdasarkan hasil penelitian ini juga diketahui bahwa secara parsial faktor motivasi dan imbalan tidak mempunyai pengaruh yang signifikan terhadap kinerja pegawai di lingkungan Sekretariat DPRD Provinsi Sumatera Selatan. Ini tentunya menjadi catatan tersendiri, sehingga di waktuwaktu mendatang membangkitkan motivasi pegawai merupakan suatu hal yang perlu terus dilakukan. Demikian juga dengan imbalan yang ternyata belum mampu memberikan pengaruh yang signifikan terhadap kinerja pegawai. Oleh karena itu di waktu-waktu mendatang diperlukan adanya perencanaan pemberian imbalan (reward) yang proporsional dan profesional. Imbalan dimaksud tidak semata-mata berupa materi dan uang (ekstrinsik), tetapi bentuk lainnya yang bersifat intrinsik.

3. Secara implikasi teoritis maka perlu dilakukan penelitian dengan jangka waktu yang memadai, sehingga penelitian dapat dilakukan dengan waktu yang cukup. 


\section{DAFTAR PUSTAKA}

Veithzal Rivai dan Ahmad Fawzi Mohd. Basri 2005, Performance Appraisal, Raja Grafindo Persada, Jakarta.

Anwar Prabu Mangkunegara 2005, Evaluasi Kinerja SDM, Refika Aditama, Bandung

Basir Barthos 2004, Manajemen Sember Daya Manusia, Suatu Pendekatan Makro, Bumi Aksara, Jakarta

Abdul Hamid Mursi 1997, SDM yang Produktif, Pendekatan AlQur'an dan Sains, Gema Insani Press, Jakarta

Husein Umar 2005, Evaluasi Kinerja Perusahaan, Gramedia Pustaka Utama, Jakarta

Indriyo Gitosudarmo dan I Nyoman Sudita 2000, Perilaku Keorganisasian, BFFE Yogyakarta, Yogyakarta

Stephen P. Robbins 2006, Perilaku Organisasi, Intans Sejati , Klaten

Onong Uchjana Effendy 2005, Ilmu Komunikasi Teori dan Praktek, Remaja Rosdakarya, Bandung

Denis H 1975, The Contraction of A Managerial Communication Climate, Chicago.

Bobbi DePorter, Mark Reardon \& Sarah Somger Nourie 2000, Quantum Teaching, Kaifa, Bandung

A. Usmara 2006, Motivasi Kerja, Proses Teori dan Praktik, Amara Books, Yogyakarta

Herzberg F. Mousner, Synderman 1995, The Motivation of Work, Jhon Wiley \& Sons, New York

B. Sapto Wibowo 2003, Sharpening Our Concept and Tools
SHOOT, Syamil Cipta Media, Bandung

Republik Indonesia, UndangUndang Nomor 32 Tahun 2004 tentang Pemerintah Daerah

Republik Indonesia, UndangUndang Nomor 33 Tahun 2004 tentang Perimbangan Keuangan antara Pusat dan Daerah

Republik Indonesia, UndangUndang Nomor 43 Tahun 1999 tentang Perubahan atas Undang-Unang Nomor 8 Tahun 1974 tentang PokokPokok Kepegawaian

Republik Indonesia, Peraturan Pemerintah Pengganti Undang-Undang Nomor 3Tahun 2005 tentang Perubahan atas UndangUndang Nomor 32 Tahun 2004 tentang Pemerintah Daerah

Hasibuan Malayu SP 2003, Organisasi dan Motivasi, Bumi Aksara, Jakarta

Husein Umar 2003, Metode Riset Bisnis, Gramedia Pustaka Utama, Jakarta

Nuruddin 2004, Sistem Komunikasi Indonesia, Raja Grafindo Persada, Jakarta

Mohammad Prabundu Tika 2006, Metodologi Riset Bisnis, Bumi Aksara, Jakarta

Suharsimi Arikunto 1996, Prosedur Penelitian Suatu Pendekatan Praktek, Rineka Cipta, Jakarta

Sugiyono 2005, Statistik Untuk Penelitian Bisnis, Alfabeta, Bandung

Davis K and Wether B Williams 1996, Human Resource Personal Management, Rustle Shaw and Wetheril Inc, New York 
Pemerintah Provinsi Sumatera

Selatan, Kebijakan Umum

Anggaran (KUA) Pemerintah

Provinsi Sumatera Selatan

Tahun 2007. 